\title{
In vitro propagation of Pterocarpus santalinus L. (Red Sandalwood) through tissue culture
}

\author{
P.S. Warakagoda* and S. Subasinghe \\ Department of Crop Science, Faculty of Agriculture, University of Ruhuna, Mapalana, Kamburupitiya.
}

\begin{abstract}
Studies have been conducted to develop an in vitro propagation protocol for Pterocarpus santalinus L., an endangered medicinal plant. Stem cuttings excised from one year old plants were surface sterilized successfully using $15 \%$ clorox $(5.25 \% \mathrm{NaOCl})$ for 10 minutes followed by $70 \%$ ethanol for two minutes and established on Mc Cowns woody plant medium (WPM) with $0.1 \%$ activated charcoal. Different explant types were tested including cotyledonary nodal segments, mesocotyl segments, in vitro derived shoot tips, immature and semi-hard wood cuttings detached from one year old plants and in vitro germinated seedlings. Maximum number of shoots and shoot branches were obtained with the Gamberg medium (B5) with $8.0 \mu \mathrm{M}$ 6-benzyle amino purine (BAP) and $2.0 \mu \mathrm{M}$ napthalene acetic acid (NAA). Adventitious roots were formed on micro shoots on half-strength solid Murashige and Skoog (MS) medium containing $0.5 \mu \mathrm{M}$ indole butric acid (IBA) after exposing to pulse treatment with $250 \mu \mathrm{M}$ IBA for 12 hours. In vitro rooted plantlets were successfully acclimatized in pots containing sand:coir dust $(1: 1)$ in a humid chamber during the first four weeks followed by keeping in a plant-house for another four weeks before repotting or field establishment.
\end{abstract}

Keywords: Explant, in vitro, in vivo, proliferation, Pterocarpus santalinus L., surface sterilization.

\section{INTRODUCTION}

Red sandalwood, Pterocarpus santalinus L. (Fabaceae), is a highly valued woody plant with dark claret-red heartwood, which contains $16 \%$ Santalin, a red colouring agent. Santal, pterocarpin and homopterocarpin are three other crystalline colouring agents present in the heartwood that are used in the pharmaceutical, paper, pulp, soap, food and textile industries to obtain a dark maroon to purple colour. In ayurvedic medicine, red sandalwood is used as an antiseptic, wound-healing agent, and in anti-acne treatments. Because of its hard texture, the red sandalwood is used in making furniture and in wood carvings. The natural habitat of $P$. santalinus is in the southern Ghats states in India, which is a hilly region with a hot dry climate. It is now considered as an endangered species and placed in the red list of endangered species under IUCN guidelines (International Union for Conservation of Nature, 2011) compelling the Indian government to ban exportation of this commodity. This decision has negatively affected Sri Lanka, as we have been importing red sandalwood from India to fulfill the national demand. In Sri Lanka, only a limited number of red sandalwood trees, which had been brought from India, are present, mainly in the southern region of the country (Arunakumara et al., 2005). Red sandalwood is conventionally propagated through seeds, which is somewhat difficult due to the hard seed coat coupled with low viability and seed dormancy due to the presence of phenolic compounds (Kumarasinghe et al., 2003).

The conventional vegetative propagation of red sandalwood has proven to be ineffective (Dayathilake et al., 2001) as the cuttings were found to be hard to root even with the application of growth regulators (Subasinghe et al., 2004). Therefore the conservation and largescale propagation of this endangered species has some inherent limitations. In this context tissue culture seems to be a promising technique for conservation and large scale multiplication of several woody species (Razdan, 1994). Studies on tissue culture of red sandalwood began in 1980s with more recent attempts to improve shoot sprouting using seedling explants in India (Anuradha \& Pullaiah, 2001). However, an efficient protocol for micropropagation of elite and quality trees of red sandalwood has not been reported to date in Sri Lanka. 
Therefore, an attempt was made to develop a feasible in vitro propagation protocol for red sandalwood through tissue culture techniques, to enable mass propagation of this plant for biodiversity conservation and to meet the increasing demand.

\section{METHODS AND MATERIALS}

Pods were picked directly from mature red sandalwood trees (over 25 years old) at the green to brownish stage. Seeds were surface sterilized using $10 \%$ clorox for 20 min followed by $70 \%$ ethanol for $2 \mathrm{~min}$ and cultured on Gamberg (B5) medium (Gamborg et al., 1968). Six different explant types were used for the study. In vitro germinated seedlings were excised after $20 \mathrm{~d}$ to derive mesocotyl segments, cotyledonatory nodal segments and shoot tips. Mother plants were maintained under plant-house conditions to excise stem cuttings. Fresh and immature terminal shoot cuttings and subsequent nodal shoot segments (semi-hard wood, $3-5 \mathrm{~cm}$ in length with dormant auxiliary buds) were collected during the early hours of the day at $2 \mathrm{wk}$ intervals. In vitro germinated 20 day old seedlings were used as the control.

As a rejuvenation procedure, decapitation and spraying of $10.0 \mathrm{ppm}$ 6-benzyle amino purine (BAP) solution was done for the mother plants, at $2 \mathrm{wk}$ intervals. Plants were maintained under plant-house conditions free from pests and diseases and watered when necessary. Overhead watering was avoided. A 100.0 ppm solution of thiophanate methyl $70 \%$ (topsin) was sprayed $24 \mathrm{~h}$ before collecting the buds for culturing to prevent fungal infections. Plants were treated with 200.0 ppm Albert's solution (complete fertilizer mixture) at $2 \mathrm{wk}$ intervals.Cultures were kept aseptically in a growth room $\left(23 \pm 2{ }^{\circ} \mathrm{C}\right.$ temperature, $\left.60 \% \mathrm{RH}\right)$ and cool white fluorescent lights were used to generate a $16 \mathrm{~h}$ photoperiod under $1220 \mathrm{~lx}$ of light intensity. All media contained $3.0 \%$ sucrose and $0.01 \%$ myo-inositol. The $\mathrm{pH}$ of the medium was adjusted to 5.8. Prepared media were autoclaved at $121{ }^{\circ} \mathrm{C}$ and $1.05 \mathrm{~kg} \mathrm{~cm}^{-2}$ pressure for $20 \mathrm{~min}$. Experiments were designed according to complete randomized design with 20 replicates in each treatment and all parametric data were analyzed using SAS statistical software. Mean separations were carried out using least significant difference test (LSD). Nonparametric data were analyzed using the Chi Square test.

\section{Surface sterilization of shoots}

Immature and semi-hard wood shoots excised from mother plants were immediately dipped in a beaker containing distilled water. In the laboratory, shoot segments were treated with liquid detergent (Teepol $5 \%$ $\mathrm{v} / \mathrm{v}$ ) for $5 \mathrm{~min}$ and placed under running tap water for half an hour. Shoots were transferred to $0.3 \%$ topsin solution and kept for $1 \mathrm{~h}$, thoroughly washed twice using sterile distilled water and transferred to different concentrations of clorox separately $(10 \%, 15 \%$ and $20 \% \mathrm{v} / \mathrm{v})$ for three different time durations (10, 15 and $20 \mathrm{~min})$. To enhance the activity of the detergent, two drops of Tween 20 (poly oxyethelene sorbitanmonolaurate) was mixed with each of the clorox solutions, introduced to $70 \%$ ethanol for 2 min and washed twice using sterile distilled water. This procedure was repeated twice. Finally, cut ends of the explants were trimmed and implanted vertically on a basal culture medium [MS (Murashige \& Skoog, 1962) or WPM (Lloyd \& McCown, 1980)]. Percentages of non contamination, browning and survivals as well as the number of shoot buds initiated and the new leaves formed were recorded over a period of $4 \mathrm{wks}$.

\section{Establishment of shoots}

Surface sterilized immature and semi-hard wood shoots were cultured on MS (Murashige \& Skoog, 1962) and WPM (Lloyd \& McCown, 1980) media with and without $0.1 \%$ activated charcoal. Percentages of browning and survivals as well as the number of shoot buds initiated and the new leaves formed were recorded over a period of 4 wks.

Effect of explant type, culture medium and combination of plant growth regulators on in vitro shoot proliferation

Separate experiments were conducted using six different types of explants. Explants were cultured on MS and B5 (Gamborg et al., 1968) media with different concentrations of BAP $(4.0,8.0$, and $12.0 \mu \mathrm{M})$ and napthalene acetic acid (NAA) $(0.5$ and $2.0 \mu \mathrm{M})$. Number of shoots, mean shoot height, number of fully opened leaves and number of branches were measured at four week intervals up to the sixth sub-culture.

Effect of pulse treatment, IBA concentration and potting media on root formation of micro cuttings

Micro shoots were dipped in three indole butric acid (IBA) concentrations (25.0, 250.0 and 2500.0 ppm) for 12 and 24 hours for pulse treatment. They were transferred to liquid and solid (by adding $0.8 \%$ agar) half strength MS media with two different IBA concentrations $(0.5$ and $5.0 \mu \mathrm{M})$. the number of roots, root length and percentage of browning were measured over a period of 4 wks. Ex vitro rooting was practiced with three IBA concentrations $(1,000.0,3,000.0$ and $5,000.0 \mathrm{ppm}$ ) and 12 and 24 hour exposure durations. Sand and sand: coir dust (1: 1) were used as two potting 
media. Root initiation rate was measured after 4 wks by uprooting the plants.

\section{Acclimatization of plantlets}

In vitro rooted plantlets were transferred to pots containing sand, coir dust, cow dung and top soil in different ratios and placed under high humid conditions in the laboratory for 2 wks. Potted plantlets were transferred to planthouse and maintained under high humidity for another 4 wks (Figure 1a).
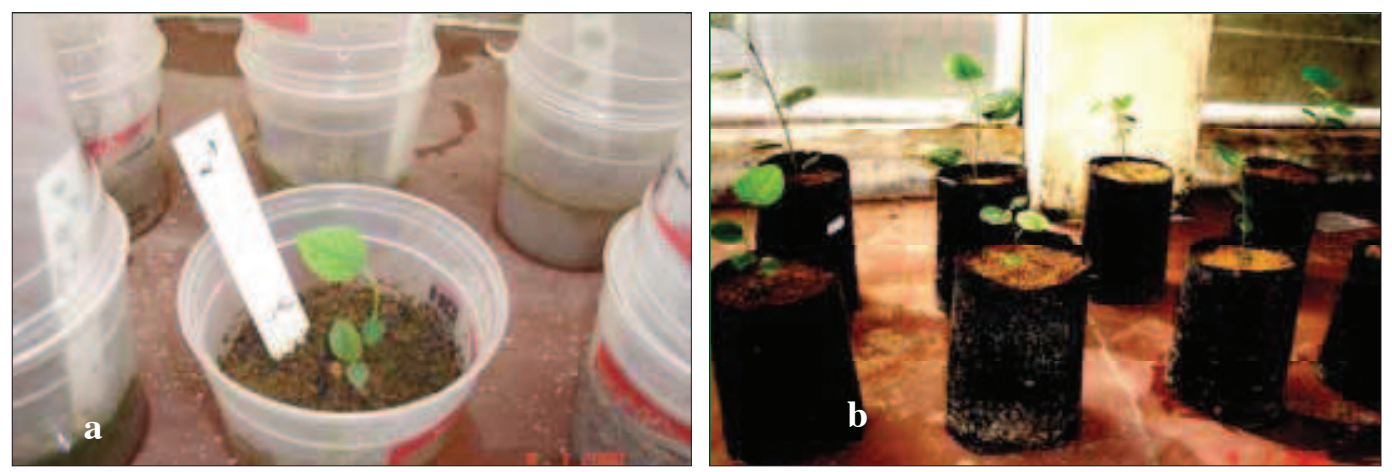

Plantlets were transferred to poly bags containing cow dung: top soil: sand (1:1:2) and placed under planthouse conditions for another 4 wks (Figure 1b). Survival rates, time taken to produce new branches, number of new leaves formed and height increment of the plants were observed over a period of 10 wks. After 4 wks, ex vitro rooted plants were transferred to poly bags with a mixture of cow dung: top soil: sand (1: 1:2) and placed under planthouse conditions for another 4 wks. Well acclimatized plantlets were finally transferred to the field.

Figure 1: a. Acclimatized plants after transferring to the plant-house; b. Plants transferred from pots into poly bags under plant-house conditions

\section{RESULTS}

\section{Surface sterilization of shoots}

The highest survival $(80 \%)$ was observed in immature cuttings treated with $15 \%$ clorox for 10 minutes. Semihard wood cuttings gave the maximum survival rate of $40 \%$ when treated with $10 \%$ clorox for 20 minutes and $15 \%$ clorox for 10 and 15 minutes (data not shown).

\section{Establishment of shoots}

There was a combined effect of media type, presence of activated charcoal and explant type on browning, which were evaluated after four weeks $(\mathrm{p} \leq 0.05)$. Activated charcoal $(0.1 \%)$ incorporated WPM medium was the best culture initiation medium for immature and semihard wood cuttings where the browning of explants was reduced to zero and $10 \%$, respectively (Table 1 ). 
Table 2: Interaction effects of medium, activated charcoal and explant type on mean number of new leaves and shoot buds formed 4 weeks after incubation

\begin{tabular}{cccc}
\hline Medium & $\begin{array}{c}\text { Interaction } \\
\text { Activated } \\
\text { charcoal }(+ \text { or }-)\end{array}$ & $\begin{array}{c}\text { Mean number } \\
\text { of new leaves }\end{array}$ & $\begin{array}{c}\text { Mean number of shoot } \\
\text { buds per explants }\end{array}$ \\
\hline MS & - & $1.22^{\mathrm{d}} \pm 0.42$ & $1.47^{\mathrm{c}} \pm 0.55$ \\
MS & + & $1.97^{\mathrm{b}} \pm 0.65$ & $1.87^{\mathrm{b}} \pm 0.72$ \\
WPM & - & $1.42^{\mathrm{c}} \pm 0.50$ & $1.42^{\mathrm{c}} \pm 0.50$ \\
WPM & + & $2.60^{\mathrm{a}} \pm 0.49$ & $2.5^{\mathrm{a}} \pm 0.50$ \\
Charcoal activated & & Explant type & \\
$(+$ or -$)$ & & $1.40^{\mathrm{d}} \pm 0.49$ & $1.85^{\mathrm{c}} \pm 0.73$ \\
- & immature & $1.25^{\mathrm{c}} \pm 0.43$ & $1.50^{\mathrm{c}} \pm 0.55$ \\
- & Semi hardwood & $2.70^{\mathrm{a}} \pm 0.46$ & $2.25^{\mathrm{a}} \pm 0.83$ \\
+ & immature & $1.87^{\mathrm{b}} \pm 0.56$ & $1.67^{\mathrm{b}} \pm 0.47$ \\
+ & Semi hardwood & $\mathrm{LSD}=0.07$ & $\mathrm{LSD}=0.07$ \\
& & $\mathrm{CV}=12.93$ & $\mathrm{CV}=14.52$ \\
\hline
\end{tabular}

Note: Means within the columns followed by the same letter are not significantly different at $\mathrm{p} \leq 0.05$

Table 3: Effects of medium, BAP and NAA concentrations on mean number of shoots produced 4 weeks after incubation

\begin{tabular}{|c|c|c|c|c|c|c|c|}
\hline \multicolumn{3}{|c|}{ Treatment combinations } & \multirow{2}{*}{$\begin{array}{c}\text { Cotyledonary } \\
\text { nodal } \\
\text { segments }\end{array}$} & \multirow[t]{2}{*}{ Mesocotyls } & \multirow{2}{*}{$\begin{array}{c}\text { In vitro } \\
\text { derived } \\
\text { shoot tips }\end{array}$} & \multirow{2}{*}{$\begin{array}{c}\text { In vitro } \\
\text { derived } \\
\text { seedlings }\end{array}$} & \multirow{2}{*}{$\begin{array}{l}\text { Immature } \\
\text { cuttings }\end{array}$} \\
\hline Medium & $\begin{array}{c}\text { BAP } \\
(\mathrm{mg} / \mathrm{L})\end{array}$ & $\begin{array}{c}\text { NAA } \\
(\mathrm{mg} / \mathrm{L})\end{array}$ & & & & & \\
\hline MS & 1 & 0.1 & $2.00^{\mathrm{g}} \pm 0.00$ & $1.35^{\mathrm{d}} \pm 0.48$ & $1.00^{\mathrm{e}} \pm 0.00$ & $1.70^{\mathrm{d}} \pm 0.70$ & $1.00^{\mathrm{d}} \pm 0.00$ \\
\hline MS & 2 & 0.1 & $2.75^{\mathrm{e}} \pm 0.44$ & $2.45^{\mathrm{c}} \pm 0.51$ & $1.50^{\mathrm{c}} \pm 0.51$ & $1.70^{\mathrm{d}} \pm 0.47$ & $1.70^{c} \pm 0.47$ \\
\hline MS & 2 & 0.4 & $3.25^{\mathrm{c}} \pm 0.44$ & $3.00^{\mathrm{c}} \pm 0.00$ & $2.00^{\mathrm{b}} \pm 0.00$ & $2.00^{\mathrm{c}} \pm 0.00$ & $2.00^{\mathrm{b}} \pm 0.00$ \\
\hline MS & 3 & 0.1 & $2.25^{\mathrm{f}} \pm 0.44$ & $2.25^{\mathrm{c}} \pm 0.44$ & $1.20^{\mathrm{d}} \pm 0.41$ & $1.55^{\mathrm{e}} \pm 0.51$ & $1.45^{\mathrm{c}} \pm 0.51$ \\
\hline MS & 3 & 0.4 & $3.30^{\mathrm{c}} \pm 0.47$ & $2.70^{c} \pm 0.47$ & $1.50^{\mathrm{c}} \pm 0.51$ & $1.70^{\mathrm{d}} \pm 0.47$ & $1.60^{c} \pm 0.50$ \\
\hline B5 & 1 & 0.1 & $3.00^{\mathrm{d}} \pm 0.00$ & $3.00^{\mathrm{c}} \pm 0.00$ & $2.00^{\mathrm{b}} \pm 0.00$ & $2.00^{\mathrm{c}} \pm 0.00$ & $2.20^{\mathrm{b}} \pm 0.41$ \\
\hline B5 & 1 & 0.4 & $3.60^{\mathrm{b}} \pm 0.50$ & $3.35^{\mathrm{b}} \pm 0.48$ & $2.15^{\mathrm{b}} \pm 0.36$ & $2.35^{\mathrm{b}} \pm 0.48$ & $2.25^{\mathrm{b}} \pm 0.44$ \\
\hline B5 & 2 & 0.1 & $3.80^{\mathrm{b}} \pm 0.41$ & $3.50^{\mathrm{b}} \pm 0.51$ & $2.10^{\mathrm{b}} \pm 0.30$ & $2.00^{c} \pm 0.00$ & $2.35^{\mathrm{b}} \pm 0.48$ \\
\hline B5 & 2 & 0.4 & $4.95^{\mathrm{a}} \pm 0.22$ & $4.00^{\mathrm{a}} \pm 0.00$ & $3.00^{\mathrm{a}} \pm 0.00$ & $3.25^{\mathrm{a}} \pm 0.44$ & $2.95^{\mathrm{a}} \pm 0.22$ \\
\hline B5 & 3 & 0.1 & $3.25^{\mathrm{c}} \pm 0.44$ & $2.65^{\mathrm{c}} \pm 0.48$ & $2.50^{\mathrm{b}} \pm 0.51$ & $2.00^{\mathrm{c}} \pm 0.00$ & $2.40^{\mathrm{b}} \pm 0.50$ \\
\hline B5 & 3 & 0.4 & $3.65^{b} \pm 0.81$ & $2.80^{c} \pm 0.83$ & $2.35^{\mathrm{b}} \pm 0.48$ & $2.30^{b} \pm 0.47$ & $2.50^{\mathrm{b}} \pm 0.51$ \\
\hline $\mathrm{CV}$ & & & 9.77 & 10.40 & 5.90 & 8.51 & 10.21 \\
\hline LSD & & & 0.08 & 0.24 & 0.23 & 0.27 & 0.22 \\
\hline
\end{tabular}

Note: Means within the columns followed by the same letter are not significantly different at $\mathrm{p} \leq 0.05$

Among the three factors tested (media type, presence of activated charcoal and explant type), only two-factor interactions significantly affected $(\mathrm{p} \leq 0.05)$ the number of leaves and the shoot buds produced. When considering the interaction between the presence of activated charcoal in the medium and type of the medium, significantly higher $(p \leq 0.05)$ number of new leaves $(2.60 \pm 0.49)$ and shoot buds $(2.50 \pm 0.50)$ were recorded in activated 
charcoal-incorporated WPM medium, compared to 1.97 \pm 0.65 new leaves and $1.87 \pm 0.72$ shoot buds produced in activated charcoal-incorporated MS medium (Table 2).

The interaction of explant type and the presence of activated charcoal in the medium significantly affected ( $p \leq 0.05)$ the number of leaves and the shoot buds produced as well. The highest number of new leaves $(2.70$ $\pm 0.46)$ and the shoot buds $(2.25 \pm 0.83)$ were formed by immature cuttings established in $0.1 \%$ activated charcoal-incorporated culture media while semi- hard wood cuttings produced $1.87 \pm 0.56$ new leaves and 1.67 \pm 0.47 shoot buds (Table 2). However, the interaction between the type of the medium and the explant type did not significantly affect $(\mathrm{p} \leq 0.05)$ on number of new leaves and shoot buds produced.

Effects of explant type, culture medium and combination of plant growth regulators on in vitro shoot proliferation

Interaction of culture medium type, BAP and NAA concentrations significantly $(p \leq 0.05)$ affected the number of shoots produced by all explant types. Significantly higher $(\mathrm{p} \leq 0.05)$ multiplication rates were observed on B5 medium supplemented with $8.0 \mu \mathrm{M}$ BAP and $2.0 \mu \mathrm{M}$ NAA (Table 3). The maximum number of shoots were recorded from cotyledonary nodal segments $(4.95 \pm 0.22)$ (Figure 2a), mesocotyl segments (4.00 \pm $0.00)$, in vitro derived shoot tips excised from 20 day old seedlings $(3.00 \pm 0.00)$, immature cuttings $(2.95 \pm$ 0.22 ) and in vitro germinated seedlings $(3.25 \pm 0.44)$, respectively at four week intervals.
Interaction of medium type, BAP and NAA concentrations significantly affected the mean shoot height $(\mathrm{p} \leq 0.05)$ of cotyledonary nodal segments, mesocotyls, in vitro derived shoot tips, immature stem cuttings (Table 4) and the control, while semi-hard wood cuttings did not show any height increment during the four week duration of culture.

Significantly higher number of shoot branches were formed by five explant types (i.e. cotyledonary nodal segments, mesocotyls, in vitro derived shoot tips, immature and semi-hard wood cuttings) on B5 medium containing $8.0 \mu \mathrm{M}$ BAP and $2.0 \mu \mathrm{M}$ NAA at $\mathrm{p} \leq 0.05$ level (Table 5). However, in vitro germinated seedlings; the control produced significantly $(\mathrm{p} \leq 0.05)$ higher number of branches $(3.09 \pm 0.22)$ on B5 medium with $4.0 \mu \mathrm{M}$ BAP and 2.0 $\mu \mathrm{M}$ NAA. During the multiplication phase, sub-culturing was practiced at four week intervals up to the sixth sub-cultures. However, after the forth subculture, the number of new shoot production was reduced drastically (data not shown).

\section{Effects of pulse treatment, IBA concentration and potting media on root formation of micro cuttings}

Pulse treatment and IBA-containing solid medium significantly $(\mathrm{p} \leq 0.05)$ affected the mean number of roots produced and the mean length of the roots (Figures $3 \& 4)$. The highest $(4.10 \pm 0.00)$ mean number of roots per shoot was produced when 2,500.0 ppm IBA solution was used for the pulse treatment with 12 hours exposure time, followed by subsequent culturing in half strength solid MS medium supplemented with $0.5 \mu \mathrm{M}$ IBA. The
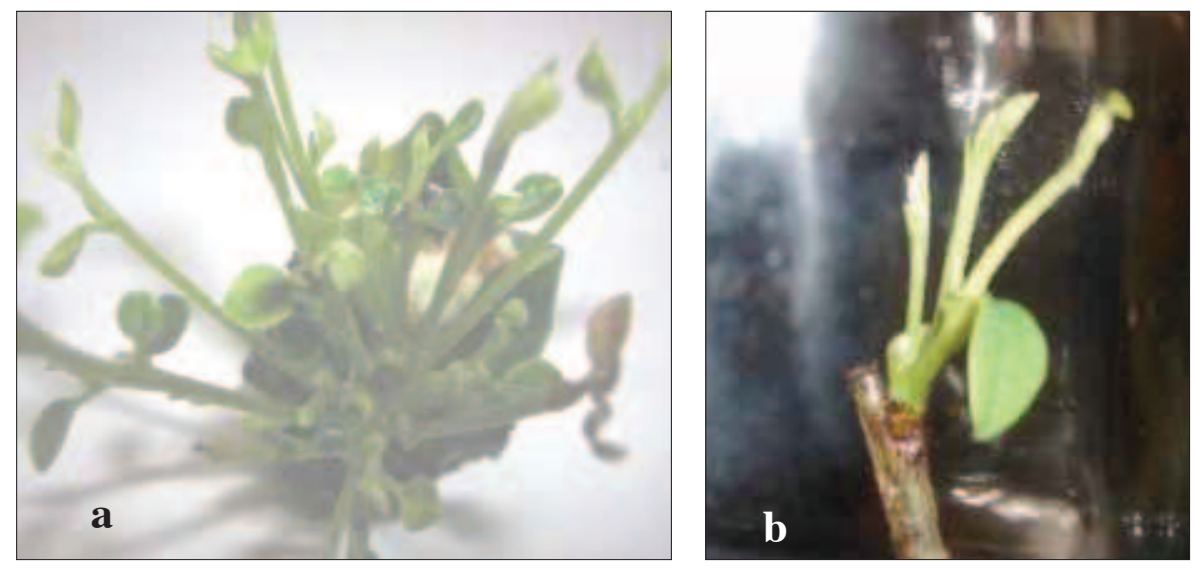

Figure 2: a. Shoots produced by a cotyledonary nodal segment after four weeks; b. New branches formed by a semi- hard wood cutting 
Table 4: Effects of culture medium, BAP and NAA concentrations on mean shoot height $(\mathrm{cm}) 4$ weeks after incubation

\begin{tabular}{|c|c|c|c|c|c|c|c|}
\hline \multicolumn{3}{|c|}{ Treatment combinations } & \multirow{2}{*}{$\begin{array}{c}\text { Cotyledonary } \\
\text { nodal } \\
\text { segments }\end{array}$} & \multirow[t]{2}{*}{ Mesocotyls } & \multirow{2}{*}{$\begin{array}{l}\text { In vitro } \\
\text { derived } \\
\text { shoot tips }\end{array}$} & \multirow{2}{*}{$\begin{array}{c}\text { In vitro } \\
\text { derived } \\
\text { seedlings }\end{array}$} & \multirow{2}{*}{$\begin{array}{l}\text { Immature } \\
\text { cuttings }\end{array}$} \\
\hline Medium & $\begin{array}{c}\text { BAP } \\
(\mathrm{mg} / \mathrm{L})\end{array}$ & $\begin{array}{l}\text { NAA } \\
(\mathrm{mg} / \mathrm{L})\end{array}$ & & & & & \\
\hline MS & 1 & 0.1 & $2.80^{\mathrm{c}} \pm 0.25$ & $3.20^{c} \pm 0.25$ & $2.60^{c} \pm 0.20$ & $2.50^{\mathrm{d}} \pm 0.0$ & $2.80^{\mathrm{c}} \pm 0.25$ \\
\hline MS & 1 & 0.4 & $3.17^{\mathrm{c}} \pm 0.24$ & $3.25^{\mathrm{b}} \pm 0.25$ & $2.75^{\mathrm{c}} \pm 0.25$ & $2.75^{\mathrm{c}} \pm 0.25$ & $3.12^{\mathrm{c}} \pm 0.22$ \\
\hline MS & 2 & 0.1 & $3.00^{c} \pm 0.00$ & $3.00^{\mathrm{b}} \pm 0.00$ & $2.85^{\mathrm{c}} \pm 0.23$ & $2.85^{\mathrm{c}} \pm 0.23$ & $3.00^{c} \pm 0.00$ \\
\hline MS & 2 & 0.4 & $3.20^{\mathrm{c}} \pm 0.25$ & $3.40^{\mathrm{b}} \pm 0.20$ & $2.95^{\mathrm{c}} \pm 0.45$ & $2.95^{\mathrm{c}} \pm 0.45$ & $3.20 \mathrm{c} \pm 0.25$ \\
\hline MS & 3 & 0.1 & $2.87^{\mathrm{c}} \pm 0.22$ & $3.12^{\mathrm{b}} \pm 0.22$ & $2.87^{\mathrm{c}} \pm 0.22$ & $2.75^{\mathrm{c}} \pm 0.25$ & $2.87^{\mathrm{c}} \pm 0.22$ \\
\hline MS & 3 & 0.4 & $3.25^{\mathrm{c}} \pm 0.25$ & $3.25^{\mathrm{b}} \pm 0.25$ & $2.75^{\mathrm{c}} \pm 0.25$ & $2.85^{\mathrm{c}} \pm 0.23$ & $3.25^{\mathrm{c}} \pm 0.25$ \\
\hline B5 & 1 & 0.1 & $3.10^{c} \pm 0.20$ & $3.30^{\mathrm{b}} \pm 0.25$ & $2.70^{c} \pm 0.25$ & $2.70^{c} \pm 0.25$ & $3.10^{\mathrm{b}} \pm 0.20$ \\
\hline B5 & 1 & 0.4 & $3.27^{\mathrm{c}} \pm 0.25$ & $3.27^{\mathrm{b}} \pm 0.25$ & $2.72^{\mathrm{c}} \pm 0.25$ & $2.72^{\mathrm{c}} \pm 0.25$ & $3.27^{\mathrm{c}} \pm 0.25$ \\
\hline B5 & 2 & 0.1 & $3.12^{\mathrm{c}} \pm 0.22$ & $3.57^{\mathrm{b}} \pm 0.43$ & $3.20^{\mathrm{b}} \pm 0.54$ & $3.52^{b} \pm 0.44$ & $3.12^{\mathrm{c}} \pm 0.22$ \\
\hline B5 & 2 & 0.4 & $3.62^{\mathrm{a}} \pm 0.22$ & $4.55^{\mathrm{a}} \pm 0.51$ & $3.92^{\mathrm{a}} \pm 0.18$ & $4.00^{\mathrm{a}} \pm 0.00$ & $3.72^{\mathrm{a}} \pm 0.25$ \\
\hline B5 & 3 & 0.1 & $3.15^{\mathrm{c}} \pm 0.23$ & $3.07^{\mathrm{b}} \pm 0.18$ & $2.92^{\mathrm{c}} \pm 0.18$ & $2.80^{\mathrm{c}} \pm 0.25$ & $3.07^{c} \pm 0.18$ \\
\hline B5 & 3 & 0.4 & $3.42^{\mathrm{b}} \pm 0.18$ & $3.50^{\mathrm{b}} \pm 0.00$ & $2.50^{\mathrm{c}} \pm 0.00$ & $2.87^{\mathrm{c}} \pm 0.22$ & $3.42^{\mathrm{b}} \pm 0.18$ \\
\hline $\mathrm{CV}$ & & & 7.25 & 8.36 & 10.02 & 9.27 & 7.0 \\
\hline LSD & & & 0.14 & 0.17 & 0.17 & 0.16 & 0.13 \\
\hline
\end{tabular}

Note: Means within the columns followed by the same letter are not significantly different at $\mathrm{p} \leq 0.05$

Table 5: Effects of culture medium, BAP and NAA concentrations on mean number of branches formed 4 weeks after incubation

\begin{tabular}{|c|c|c|c|c|c|c|c|}
\hline \multicolumn{3}{|c|}{ Treatment combinations } & \multirow{2}{*}{$\begin{array}{c}\text { Cotyledonary } \\
\text { nodal } \\
\text { segments }\end{array}$} & \multirow[t]{2}{*}{ Mesocotyls } & \multirow{2}{*}{$\begin{array}{l}\text { In vitro } \\
\text { derived } \\
\text { shoot tips }\end{array}$} & \multirow{2}{*}{$\begin{array}{l}\text { In vitro } \\
\text { derived } \\
\text { seedlings }\end{array}$} & \multirow{2}{*}{$\begin{array}{l}\text { Immature } \\
\text { cuttings }\end{array}$} \\
\hline Medium & $\begin{array}{c}\text { BAP } \\
(\mathrm{mg} / \mathrm{L})\end{array}$ & $\begin{array}{l}\mathrm{NAA} \\
(\mathrm{mg} / \mathrm{L})\end{array}$ & & & & & \\
\hline MS & 1 & 0.1 & $0.00^{\mathrm{d}} \pm 0.00$ & $0.00^{\mathrm{d}} \pm 0.00$ & $0.00^{\mathrm{e}} \pm 0.00$ & $0.00^{\mathrm{e}} \pm 0.00$ & $0.00^{\mathrm{d}} \pm 0.00$ \\
\hline MS & 1 & 0.4 & $0.00^{\mathrm{d}} \pm 0.00$ & $0.00^{\mathrm{d}} \pm 0.00$ & $0.00^{\mathrm{e}} \pm 0.00$ & $0.00^{\mathrm{e}} \pm 0.00$ & $0.00^{\mathrm{d}} \pm 0.00$ \\
\hline MS & 2 & 0.1 & $0.00^{\mathrm{d}} \pm 0.00$ & $0.00^{\mathrm{d}} \pm 0.00$ & $0.00^{\mathrm{e}} \pm 0.00$ & $0.00^{\mathrm{e}} \pm 0.00$ & $0.00^{\mathrm{d}} \pm 0.00$ \\
\hline MS & 2 & 0.4 & $0.00^{\mathrm{d}} \pm 0.00$ & $0.00^{\mathrm{d}} \pm 0.00$ & $0.00^{\mathrm{e}} \pm 0.00$ & $0.00^{\mathrm{e}} \pm 0.00$ & $0.00^{\mathrm{d}} \pm 0.00$ \\
\hline MS & 3 & 0.1 & $0.00^{\mathrm{d}} \pm 0.00$ & $0.00^{\mathrm{d}} \pm 0.00$ & $0.00^{\mathrm{e}} \pm 0.00$ & $0.00^{\mathrm{e}} \pm 0.00$ & $0.00^{\mathrm{d}} \pm 0.00$ \\
\hline MS & 3 & 0.4 & $0.00^{\mathrm{d}} \pm 0.00$ & $0.00^{\mathrm{d}} \pm 0.00$ & $0.00^{\mathrm{e}} \pm 0.00$ & $0.00^{\mathrm{e}} \pm 0.00$ & $0.00^{\mathrm{d}} \pm 0.00$ \\
\hline B5 & 1 & 0.1 & $3.00^{c} \pm 0.00$ & $2.00^{c} \pm 0.00$ & $1.00^{\mathrm{d}} \pm 0.00$ & $1.30^{\mathrm{d}} \pm 0.47$ & $1.30^{c} \pm 0.47$ \\
\hline B5 & 1 & 0.4 & $3.55^{\mathrm{b}} \pm 0.51$ & $2.55^{\mathrm{b}} \pm 0.51$ & $1.00^{\mathrm{d}} \pm 0.00$ & $1.85^{\mathrm{c}} \pm 0.36$ & $2.00^{\mathrm{b}} \pm 0.00$ \\
\hline B5 & 2 & 0.1 & $3.00^{\mathrm{c}} \pm 0.00$ & $2.00^{\mathrm{c}} \pm 0.00$ & $1.25^{\mathrm{c}} \pm 0.44$ & $2.40^{b} \pm 0.50$ & $2.00^{c} \pm 0.00$ \\
\hline B5 & 2 & 0.4 & $4.20^{\mathrm{a}} \pm 0.00$ & $3.75^{\mathrm{a}} \pm 0.71$ & $2.50^{\mathrm{a}} \pm 0.51$ & $3.15^{\mathrm{a}} \pm 0.58$ & $3.45^{\mathrm{a}} \pm 0.51$ \\
\hline B5 & 3 & 0.1 & $3.00^{c} \pm 0.00$ & $2.00^{\mathrm{c}} \pm 0.00$ & $1.00^{\mathrm{d}} \pm 0.00$ & $1.15^{\mathrm{d}} \pm 0.15$ & $1.00^{c} \pm 0.00$ \\
\hline B5 & 3 & 0.4 & $3.60^{b} \pm 0.75$ & $2.65^{\mathrm{b}} \pm 0.81$ & $1.30^{\mathrm{b}} \pm 0.47$ & $1.12^{\mathrm{d}} \pm 0.19$ & $1.30^{b} \pm 0.47$ \\
\hline $\mathrm{CV}$ & & & 10.37 & 12.03 & 15.54 & 17.95 & 13.67 \\
\hline LSD & & & 0.05 & 0.05 & 0.05 & 0.07 & 0.05 \\
\hline
\end{tabular}

Note: Means within the columns followed by the same letter are not significantly different at $\mathrm{p} \leq 0.05$ 


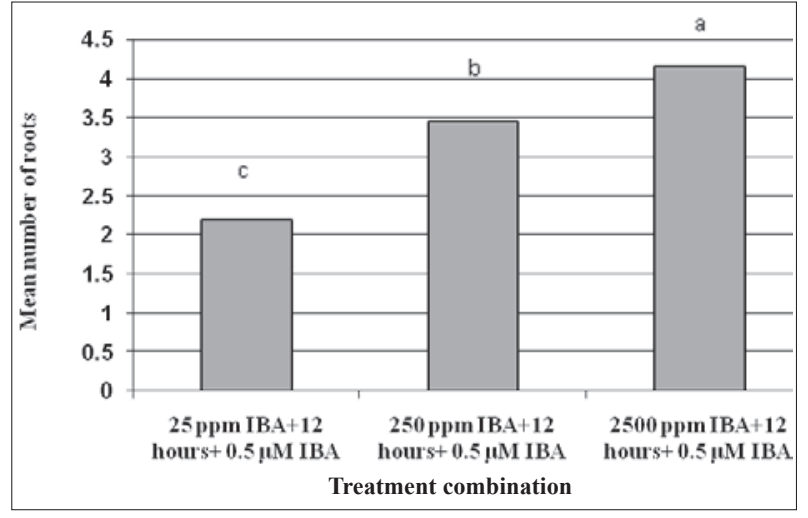

$\mathrm{CV}: 14.15, \mathrm{LSD}=0.03$

Figure 3: Mean number of roots as affected by pulse treatment and incorporated IBA concentrations into the culture medium (4 weeks after incubation)

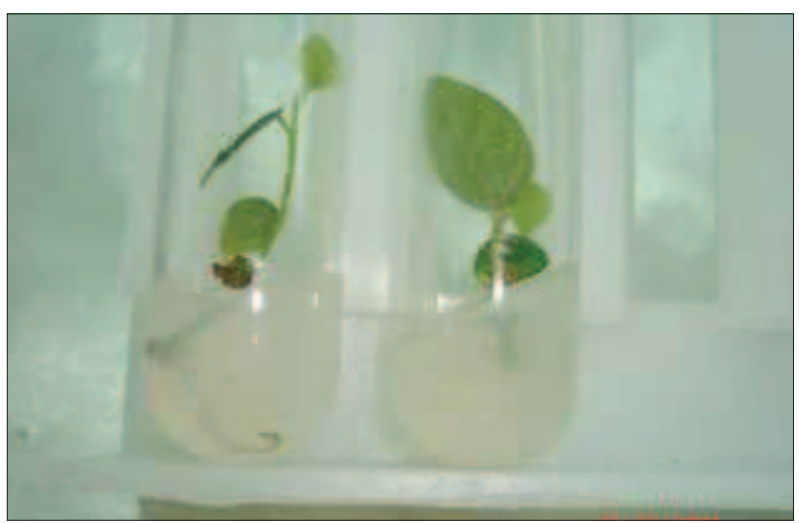

Figure 5: Shoots rooted on 0. $5 \mu \mathrm{M}$ IBA containing $1 / 2$ strength MS medium after dipping in $25.0 \mathrm{ppm}$ IBA solution for 12 hours

mean root length was the highest $(2.67 \pm 0.71 \mathrm{~cm})$ in the shoots treated with $25.0 \mathrm{ppm}$ IBA for 12 hours exposure time with subsequent culturing on half strength solid MS medium supplemented with $0.5 \mu \mathrm{M}$ IBA (Figure 5 ). However the lowest mean number of roots per shoot $(2.20 \pm 0.51)$ was observed in the above treatment.

IBA concentrations and exposure times used for the pulse treatment had significant effects on the browning of shoots at $\mathrm{p} \leq 0.05$ probability level. Exposure times of the pulse treatment and the concentrations of the IBAincorporated into the rooting medium significantly $(\mathrm{p} \leq$

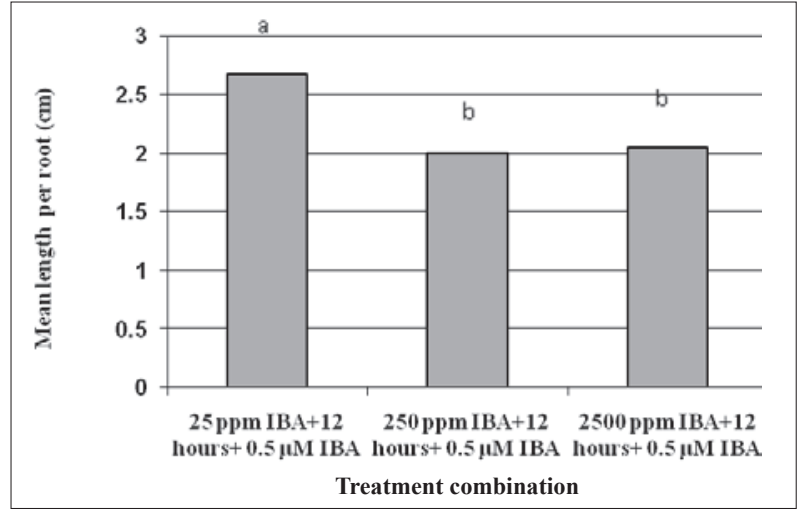

CV: $8.40, \mathrm{LSD}=0.01$

Figure 4: Mean root length as affected by pulse treatment and incorporated IBA concentrations into the culture medium (4 weeks after incubation)

0.05 ) affected the browning of shoots as well (Table 6). Pulse treatment with 25.0, 250.0 and 2,500.0 ppm IBA for 24 hours followed by culturing on 0.5 or $5.0 \mu \mathrm{M}$ IBA supplemented media, caused browning and subsequent deaths of shoots (Table 6).

When shoots were pulse treated with $2,500.0 \mathrm{ppm}$ IBA for 12 hours followed by transferring to liquid half strength MS medium fortified with $0.5 \mu \mathrm{M}$ IBA, $100 \%$ rooting was observed within four weeks of incubation. However, they were fragile in nature and did not show any further growth and turned brown (Figure 6). Shoots pulse treated with $25.0 \mathrm{ppm}$ and $250.0 \mathrm{ppm}$ IBA for 12 hours followed by transferring to liquid half strength MS medium fortified with $0.5 \mu \mathrm{M}$ or $5.0 \mu \mathrm{M}$ IBA never produced roots.

Shoots dipped in $1,000.0 \mathrm{ppm}$ IBA solution for 12 hours and subsequently transferred into sand medium produced $40 \%$ rooting while none of the other treatments produced roots (Figure 7).

\section{Acclimatization of plantlets}

An $80 \%$ success rate was observed, when the plantlets were acclimatized in sand : coir dust (1:1) potting medium, with increasing plant heights and production of new leaves and shoot branches (data not shown). A two-stage acclimatization procedure (six weeks under high humidity and low light followed by another four weeks in a plant-house under shade) was needed prior to establishment in the field. 
Table 6: Interaction effects of exposure time and IBA concentrations on browning of explants 4 weeks after incubation $(\mathrm{n}=20)$

\begin{tabular}{ccc}
\hline $\begin{array}{c}\text { IBA concentration } \\
(\mathrm{mg} / \mathrm{L})\end{array}$ & Exposure time & Browning \\
\hline 25 & 12 hours & $0.00^{\mathrm{d}} \pm 0.00$ \\
25 & 24 hours & $82.50^{\mathrm{b}} \pm 7.07$ \\
250 & 12 hours & $0.00^{\mathrm{d}} \pm 0.00$ \\
250 & 24 hours & $87.50^{\mathrm{b}} \pm 10.35$ \\
2500 & 12 hours & $0.00^{\mathrm{d}} \pm 0.00$ \\
2500 & 24 hours & $95.00^{\mathrm{a}} \pm 9.25$ \\
& & $\mathrm{LSD}=5.70$ \\
\hline Exposure time & IBA concentration in the \\
& medium $(\mathrm{mg} / \mathrm{L})$ & \\
\hline 12 hours & 0.1 & $0.00^{\mathrm{c}} \pm 0.00$ \\
12 hours & 1.0 & $0.00^{\mathrm{c}} \pm 0.00$ \\
24 hours & 0.1 & $85.00^{\mathrm{b}} \pm 9.04$ \\
24 hours & 1.0 & $91.66^{\mathrm{a}} \pm 10.29$ \\
& & $\mathrm{LSD}=4.66$
\end{tabular}

Note: Means within the last column followed by the same letter are not significantly different at $\mathrm{p} \leq 0.05$

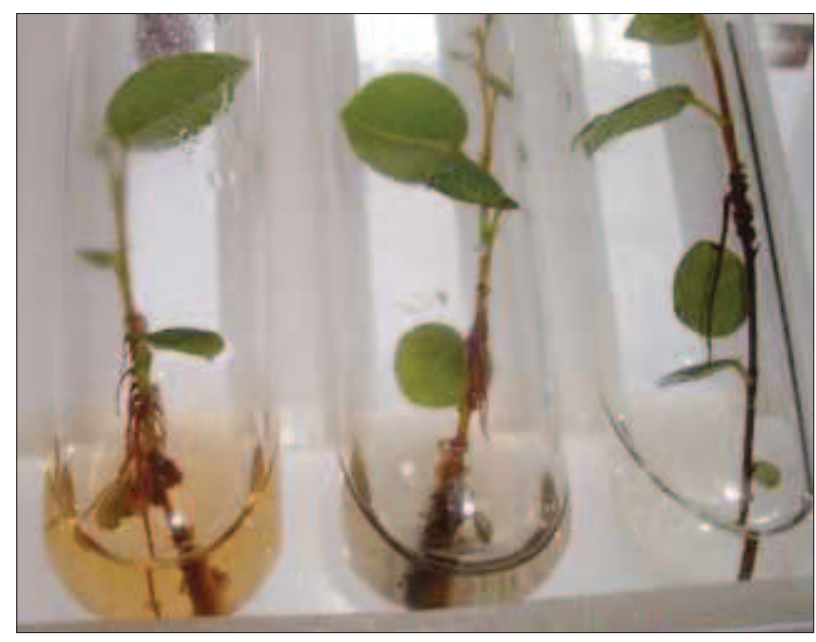

Figure 6: Shoots in $1 / 2$ strength liquid MS medium treated with 2,500.0 ppm IBA solution for 12 hours, produced roots in fragile nature

\section{DISCUSSION AND CONCLUSION}

\section{Surface sterililzation procedure for shoots}

During the present study, immature stem cuttings of $P$. santalinus were successfully surface sterilized using $15 \%$ clorox with 10 minutes exposure time followed by $70 \%$ ethanol for 2 minutes exposure time resulting 80 $\%$ non-contamination rate, $80 \%$ survival rate and 100 $\%$ non-browning rate. The use of mercuric chloride for surface sterilization of explants has been reported in many research articles. Prakash et al. (2006) reported that double sterilization using $70 \%$ ethanol for 2 minutes followed by $0.1 \%(\mathrm{w} / \mathrm{v})$ aqueous mercuric chloride solution for 7 minutes yielded $80 \%$ of contamination free nodal explants in $P$. santalinus. S. album nodal shoot segments surface sterilized with $0.075 \%(\mathrm{w} / \mathrm{v})$ mercuric chloride for 5- 6 minutes were reported to have a $90 \%$ survival rate (Sanjaya et al., 2006). However, it is a hazardous chemical with problems of disposal. Therefore, it is more eco-friendly and beneficial to find a surface sterilization procedure that does not use mercuric chloride. The present study demonstrates the applicability of $15 \%$ clorox for 10 minutes followed by $70 \%$ ethanol for 2 minutes as surface sterilization agents for immature stem cuttings of $P$. santalinus.

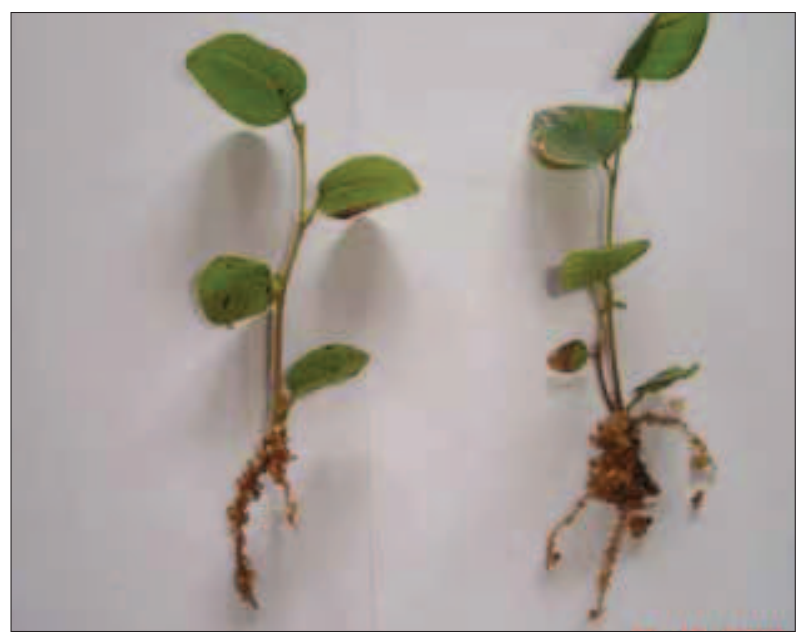

Figure 7: Ex vitro rooting of micro shoots after treated with 1,000.0 ppm IBA solution for 12 hours 


\section{Establishment of shoots}

In the present study, survival rates (number of explants that remained green without contamination for four weeks after culture initiation) were found to be dependent on the type of the medium, presence of activated charcoal in the medium and explant type $(\mathrm{p} \leq 0.05)$. WPM was found to be the best medium with the highest survival rate when compared to MS medium. Incorporation of activated charcoal into the culture medium reduced the browning by absorbing phenolic compounds and other exudates, enhancing the growth performance of explants and showed higher survival rate when compared to the media without activated charcoal. Immature stem cuttings showed higher survival rate than semi-hard wood cuttings.

It has been demonstrated that leaching of phenolic compounds from cut ends of nodal explants into the liquid nutrient medium could be controlled by the combination of serial transfer technique at intervals of 24, 48, 72 and 96 hours and the incorporation of antioxidants $(250.0$ ppm ascorbic acid and $50.0 \mathrm{ppm}$ citric acid) into the culture media for $P$. santalinus immature stem cuttings from 10 year old trees with $70 \%$ survival (Prakash et al., 2006). In the present study, immature cuttings cultured on $0.1 \%$ activated charcoal incorporated WPM medium achieved $100 \%$ survival rate without browning and with higher numbers of new leaves and shoot buds, thus showing that the WPM medium incorporated with $0.1 \%$ activated charcoal is a better establishment medium for immature stem cuttings of $P$. santalinus.

Effects of explant type, culture medium and combination of plant growth regulators on in vitro shoot proliferation

It has been shown that cotyledonary nodal segments cultured on MS medium supplemented with BAP $(5.0 \mu \mathrm{M})$ achieved maximum shoot multiplication $(7.83 \pm 0.30)$ per explant within six weeks and that higher concentrations of BAP and Kinetin decreased the multiplication rates of Pterocarpus marsupium while incorporation of low levels $(0.25-1.00 \mu \mathrm{M})$ of indol acetic acid (IAA) or NAA along with BAP induced shoot bud initiation (Anis et al., 2005). Prakash et al (2006) reported that a combination of BAP and different auxins (IAA or NAA) did not improve the shoot proliferation of $P$. santalinus, whereas BAP and thidiazuron (TDZ) stimulated the production of new shoots with a 3.5 multiplication coefficient in MS medium for nodal explants. However, during the current study, cotyledonary nodal segments produced a higher mean number of shoots, $(4.95 \pm 0.22)$ when compared to mesocotyls $(4.00 \pm 0.00)$, in vitro germinated seedlings; the control $(3.25 \pm 0.44)$, in vitro derived shoot tips $(3.00 \pm 0.00)$ and immature cuttings $(2.95 \pm 0.22)$ on B5 medium containing $8.0 \mu \mathrm{M}$ BAP and $2.0 \mu \mathrm{M}$ NAA (Table 3) within four weeks and up to the forth subculture while no multiplication was observed in semihard wood cuttings.

Anis et al, (2005) reported that 5.0 $\mu \mathrm{M}$ BAP and 0.25 $\mu \mathrm{M}$ IAA in MS medium gave the highest mean height $(4.01 \pm 0.06 \mathrm{~cm})$ per shoot for $P$. marsupium using cotyledonary nodal segments and Prakash et al. (2006) showed that a combination of $4.4 \mu \mathrm{M}$ BAP and $2.2 \mu \mathrm{M}$ TDZ produced shoots with 6-7 $\mathrm{cm}$ mean length per shoot for $P$. santalinus using nodal segments. During the current study, $8.0 \mu \mathrm{M}$ BAP with $2.0 \mu \mathrm{M}$ NAA without TDZ gave a mean shoot height of $4.55 \pm 0.51 \mathrm{~cm}$ for mesocotyls, $4.00 \pm 0.00 \mathrm{~cm}$ for immature cuttings, $3.92 \pm$ $0.18 \mathrm{~cm}$ for in vitro excised shoot tips, $3.72 \pm 0.25$ for the control and $3.62 \pm 0.22$ for cotyledonary nodal segments (Table 4). These heights are capable of being transferred to further multiplication or root formation. Semi-hard wood cuttings did not show any height increment during the four week duration of culture.

Red sandalwood is a plant with a higher branching habit, producing side shoots frequently near the soil surface, not only due to apical bud damage but also when it bends due to shade conditions. This is common to in vitro cultures as well, with cotyledonary nodal segments producing more branches $(4.20 \pm 0.00)$ than mesocotyls $(3.75 \pm 0.71)$ (Table 5) and controls (3.09 \pm 0.22$)$, and semi-hard wood cuttings producing more branches $(3.45$ $\pm 0.51)$ (Figure $2 \mathrm{~b}$ ) than in vitro derived shoot tips $(2.50$ \pm 0.51 and immature cuttings $(3.15 \pm 0.58)$ (Table 5), which may be governed by the phenomenon of apical dominance. To obtain the above results, explants have to be cultured on B5 medium containing $8.0 \mu \mathrm{M}$ BAP and $2.0 \mu \mathrm{M}$ NAA. These branches can also be used as stem cuttings to form roots.

B5 medium fortified with $8.0 \mu \mathrm{M}$ BAP and $2.0 \mu \mathrm{M}$ NAA was the best medium and plant growth regulator combination to form the highest number of new shoots and new shoot branches from cotyledonary nodal segments, mesocotyls, in vitro derived shoot tips, immature and semi-hard wood cuttings and in vitro germinated seedlings, respectively within a four week interval. Mesocotyls gave the highest mean shoot height under the same conditions. The regeneration ability was reduced drastically after the forth sub-culture. 
Effects of pulse treatment, IBA concentration and potting media on root formation of micro cuttings

As a woody perennial, red sandalwood is difficult to root. Stem cuttings even treated with higher concentrations of auxins up to $3000.0 \mathrm{ppm}$ failed to produce roots (Subasinghe et al., 2004). Sanjaya et al (2006) reported that the best results for $S$. album shoots were given when exposed to pulse treatment with $98.4 \mu \mathrm{M}$ IBA for 48 hours to induce rooting and subsequently cultured on MS medium. Isolated micro shoots of $P$. marsupium have been rooted using a strategy of giving pulse treatment of an auxin (IBA; $200.0 \mu \mathrm{M}$ ) together with a phenolic acid for 5 days and subsequent transfer to lower concentrations of auxin (IBA; $0.5 \mu \mathrm{M}$ ) on half MS medium (Anis et al., 2005).

Prakash et al. (2006) has reported that P. santalinus shoots derived from in vitro multiplication were rooted on half strength MS medium supplemented with $4.9 \mu \mathrm{M}$ IBA, failed to produce more than one root. During the current study, it was seen that without pulse treatment, a range of IBA, IAA and NAA $(0.5 \mu \mathrm{M}$ IBA to $5.0 \mu \mathrm{M}$ IBA) concentrations were not effective in root formation. Stem cuttings with $2.0 \mathrm{~cm}$ length treated with $250.0 \mathrm{ppm}$ IBA solution for 12 hours followed by transferring to half strength solid MS medium containing $0.5 \mu \mathrm{M}$ IBA formed roots successfully.

\section{Acclimatization of plantlets}

The present study revealed that in vitro rooted plantlets could be successfully acclimatized in potting media containing sand : coir dust 1:1 ratio. Eighty percent survival was observed when the plantlets were placed in a humid chamber during the first six weeks and maintained under plant-house conditions for another four weeks before repotting or field establishment.

Somewhat similar results were recorded by Prakash et al., (2006) where $70 \%$ survival was seen among in vitro rooted plantlets of $P$. santalinus acclimatized in a plant-growth chamber at $25 \pm 2{ }^{\circ} \mathrm{C}$ and $85 \% \mathrm{RH}$ under 16 hour photoperiod provided by cool white fluorescent tubes for two weeks. The plantlets were then transferred to a shady area of a forest nursery for another four weeks after repotting in larger $20 \mathrm{~cm}$ pots containing a mixture of soil and farmyard manure $(4: 1)$. It is therefore seen that the acclimatization procedure developed in the current study could be effectively applied to acclimatize in vitro rooted plantlets of $P$. santalinus. It can be concluded that Pterocarpus santalinus could be propagated on massscale using the micropropagation protocol reported in this study, which would serve to fulfill the island wide demand for this plant

\section{REFERENCES}

1. Anis M., Husain M.K. \& Shahzad A. (2005). In vitro plant regeneration of Pterocarpus marsupium Roxb., an endangered leguminous tree. Current Science 88(6): 861 -863 .

2. Anurdha M. \& Pullaiah T. (2001). Propagation studies of Red sanders (Pterocarpus santalinus L. f.) in- vitro. Taiwania 44(3): 311 - 324.

3. Aruna Kumara K.K.I.U., Wikramasinghe U., Subasinghe S. \& Walpola B.C. (2005). An assessment of Rath Handun (Pterocarpus santalinus Linn. f.), Proceedings of the $61^{\text {st }}$ Annual Sessions, Sri Lanka Association for the Advancement of Science, pp. 106.

4. Dayatilake G.A., Aruna Kumara K.K.I.U., Kumari D.L.C. \& Senarathne R. (2001). Conservation and propagation of red sanders (Pterocarpus santalinus Lin.), Proceedings of the $7^{\text {th }}$ Forestry and Environmental Symposium, Sri Lanka, pp. 49.

5. Gamborg O.L. \& Philips G.C. (1967). Plant Tissue and Organ Culture Fundamental Methods, $3^{\text {rd }}$ edition. SpringerVerlag Publishers, Berlin, Germany.

6. Gamborg O.L., Millar R.A. \& Ojima K. (1968). Nutrient requirements of suspension cultures of soyabean root cells. Experimental Cell Research 50: $151-158$.

7. Kumarasinghe H.K.M.S., Subasinghe S. \& Aruna Kumara K.K.I.U. (2003). Seed propagation of Rath Handun (Pterocarpus santalinus L.) as affected by method of soaking and scarification, Proceedings of the $9^{\text {th }}$ Annual Forestry and Environment Symposium, Sri Lanka, pp. 57.

8. Lloyd G. \& McCown B. (1980). Commercially feasible micro-propagation of Mountain Laurel (Kalmia latifolia), by use of shoot tip culture. Proceedings of the International Plant Propagators Society 30: $421-427$.

9. Murashige T. \& Skoog F. (1962). A revised medium for rapid growth and bioassays with tobacco tissue cultures. Plant Physiology 15(3): 473 - 497.

10. Prakash E., Khan P.S.S.V., Rao T.J.V.S. \& Meru E.S. (2006). Micropropagation of red sanders (Pterocarpus santalinus L.) using mature nodal explants. Journal of Forest Research 11: 329 - 335.

11. Razdan M.K. (1994). An introduction to Plant Tissue Culture, $2^{\text {nd }}$ edition. Raju Primlani for Oxford and IBH publishing Co. Pvt. Ltd., India.

12. Sanjaya B.M., Rathore T.S. \& Rai V.R. (2006). Micropropagation of an endangered Indian Sandalwood (Santalinus album L.). Journal of Forest Research 11: 203 $-209$.

13. Subasinghe S., Arunakumara K.K.I.U. \& Kumarasinghe H.K.M.S. (2004). Development of cost effective propagation technique for Rath Handun (Perocarpus santalinus). Proceedings of the CONSSUMPP Symposium; National Seminar on Medicinal Plants, Colombo, Sri Lanka. 
14. Taize L. \& Zeiger E. (2002). Plant Physiology, $3^{\text {rd }}$ edition, pp. 68 - 79, 424 - 586. Sinauer Associates, Inc., USA.

15. The IUCN (2011). Red List of Threatened Species.
International Union for Conservation of Nature. Available at http://www.iucnredlist.org/apps/redlist/details/32104/0, Accessed 20 August 2011. 